\title{
Geminus Christi. \\ La excomunión de la placenta en los relatos del nacimiento virginal
}

\author{
GERMÁN OSVALDO PRÓSPERI* \\ Universidad Nacional de La Plata (Argentina) \\ gerprosperi@hotmail.com
}

\begin{abstract}
Resumen
En este artículo nos proponemos mostrar que el nacimiento virginal de Jesús se ha constituido, en su sentido dogmático, a partir de una obliteración de la placenta. Para las culturas primitivas, la placenta era considerada un doble o un gemelo (alter ego) del feto. Mostraremos que el peligro de introducir la figura de la placenta en los relatos del nacimiento virginal implicaba la posibilidad de que existiese un doble o un alter ego del Salvador. Para nosotros, este doble o gemelo coincide con la figura del Anticristo.
\end{abstract}

Palabras clave: placenta, nacimiento virginal, vientre, ombligo, Cristo, Anticristo.

\section{'Geminus Christi'. \\ The excommunication of the placenta in the virgin birth narratives}

\begin{abstract}
This article aims at demonstrating that the virgin birth of Christ has been construed, in its dogmatic sense, based on the obliteration of the placenta. Primitive cultures regarded the placenta as a double or twin (alter ego) of the fetus. We will demonstrate that introducing the placenta into virgin birth narratives dangerously implied the potential of a double or alter ego of the Saviour. In our view, this double or twin brother refers to the Antichrist.
\end{abstract}

Key words: placenta, virgin birth, womb, navel, Christ, Antichrist.

\footnotetext{
* Doctor en filosofía por la Universidad Nacional de La Plata, Argentina. Es autor de los libros: Vientres que bablan. Ventriloquia y subjetividad en la historia occidental (2015), La respiración del Ser. Apnea y ensueño en la filosofía hegeliana (2018) y La máquina óptica. Antropología del fantasma y (extra)ontología de la imaginación (2019). Ha publicado además diversos artículos en revistas especializadas, tanto nacionales cuanto internacionales. Actualmente se desempeña como docente e investigador en la Facultad de Humanidades y Cs. de la Educación (Universidad Nacional de La Plata).
} 


\section{INTRODUCCIÓN}

Si bien el nacimiento virginal de Jesús no es el eje fundamental de la fe cristiana, constituye sin embargo, como ha señalado Philip. W. Crannell, "una de sus piedras angulares" (1932: 362). Más allá de las innumerables discusiones que se han suscitado a lo largo de los siglos acerca de este acontecimiento ${ }^{1}$, lo cierto es que se estableció, casi desde el inicio mismo del cristianismo, como uno de los pilares del dogma: "La doctrina del nacimiento virginal de Cristo fue universalmente aceptado como parte de la Fe cristiana en el segundo siglo d.C." (Wilkinson, 1964: 164). El propio Wilkinson, además, explica qué debe entenderse por nacimiento virginal del Salvador: "Por la expresión el nacimiento virginal de Cristo entendemos la doctrina según la cual Jesucristo nació de la Virgen María sin requerir la intervención biológica normal de un ser humano masculino" (1964: 160; el subrayado es de Wilkinson)2. Las dos referencias bíblicas más importantes en relación al nacimiento de Jesús se encuentran en los Evangelios de Mateo y Lucas. ${ }^{3}$ En el caso de Mateo, además, se menciona el célebre pasaje de Isaías 7:11. Dada la importancia de estos versículos nos permitimos citarlos in extenso:

El nacimiento de Jesucristo fue así: Estando María su madre desposada con José, antes que se juntasen, se halló que en su vientre [en gastri] había concebido del Espíritu Santo [ek pneumatos hagiou] [...] Y he aquí el ángel del Señor le apareció [a José] en un sueño, diciendo: José hijo de David, no temas recibir a María tu esposa, porque lo que en ella es engendrado, del Espíritu Santo es [gennèthen ek, pneumatos estin hagiou]. Y dará a luz un hijo, y llamarás su nombre Jesús; porque Él salvará a su pueblo de sus pecados. Todo esto aconteció para que se cumpliese lo que fue dicho del Señor, por el profeta que dijo: He aquí una virgen [béparthenos] concebirá en su vientre [en gastri] y dará a luz un hijo, y llamarás su nombre Emmanuel, que interpretado es: Dios con nosotros. (Mateo 1:18-23) 4

1 Para un panorama general del nacimiento virginal de Cristo, véase Machen, 1958; Warner, 1976: 35-50.

2 No debe confundirse esta doctrina, por supuesto, con la inmaculada concepción, la cual hace referencia al dogma católico que sostiene que la virgen María estuvo libre del pecado original desde el primer momento de su concepción.

3 Para un análisis de los relatos del nacimiento virginal de Cristo en los Evangelios de Mateo y Lucas, véase Brown, 1993.

$4 \quad$ La traducción de los textos bíblicos es, preferentemente, la de Reina Valera Gómez 2010. En algunos casos, la hemos modificado ligeramente, atendiendo siempre al texto original. Aclaramos también que a lo largo de este artículo hemos utilizado como criterio de transliteración de los términos griegos las normas ALA-LC 2010. 
En el Evangelio de Lucas, el ángel Gabriel se le presenta a María y le anuncia:

Y he aquí, concebirás en tu vientre [en gastri], y darás a luz un hijo, y llamarás su nombre Jesús. [...] Entonces María dijo al ángel: ¿Cómo será esto? pues no conozco varón. Y respondiendo el ángel le dijo: El Espíritu Santo vendrá sobre ti [pneuma hagion epeleusetai epi se], y el poder del Altísimo te cubrirá con su sombra; por lo cual también lo Santo que de ti nacerá [to gennömenon hagion], será llamado el Hijo de Dios [Huios Theou]. (Lucas 1:31-35)

Como puede observarse, el vientre (gaster o koilia) ${ }^{5}$ de María se convierte en el lugar simbólico en el que el Verbo se hace carne. Allí, en las profundidades del vientre, particularmente en el útero, la divinidad se une (sin confusión ni mezcla, pero sobre todo sin separación) con la humanidad $^{6}$, el espíritu santo se une con la carne humana. La importancia simbólica del vientre de María, entendido como locus coniunctionis, es decir como el lugar en el que lo divino se une o conjuga con lo humano, queda demostrada pocos versículos después. En efecto, luego del anuncio del ángel Gabriel, María visita a su prima Isabel; ésta, al verla, exclama las palabras que, tiempo después, pasarán a formar parte del Avemaría: "Bendita tú entre las mujeres, y bendito el fruto de tu vientre [ho karpos tès koilias sou]" (Lucas 1: 42)7. El vientre, por cierto, en tanto locus coniunctionis, es digno de ser bendecido; en él y a través de él, Dios entra en la historia humana.

Ahora bien, en este artículo quisiéramos mostrar que los relatos del nacimiento virginal de Cristo se han constituido a partir de una oblitera-

5 El término vientre, aquí, tiene el sentido de matriz o lugar de concepción y no el sentido negativo que lo vincula al alma apetitiva del platonismo. Sobre el problema del vientre como asiento del alma apetitiva en Platón, véase Prósperi, 2015: 81-93.

6 Con estas palabras nos referimos, por supuesto, al célebre dictum decretado en el Concilio de Calcedonia. Se recordará el texto principal (sesión V, definición 34): "se ha de reconocer a uno solo y el mismo Cristo Hijo Señor unigénito en dos naturalezas, sin confusión, sin cambio, sin división, sin separación, en modo alguno borrada la diferencia de naturalezas por causa de la unión, sino conservando, más bien, cada naturaleza su propiedad y concurriendo en una sola persona y en una sola hipóstasis..." Sobre el Concilio de Calcedonia, véase Grillmeier, 1975: 488-519. Puede consultarse una traducción inglesa de las Actas del Concilio en Price \& Gaddis, 2005; el pasaje recién citado corresponde a la p. 204.

${ }^{7}$ Tertuliano hace referencia a este pasaje en el De carne Christi para demostrar la naturaleza humana del Salvador: "Si María llevaba en su vientre a Jesús como un huésped y no como un hijo, ¿por qué Isabel habría dicho 'bendito es el fruto de tu vientre’? ¿Qué clase de fruto del vientre sería si no hubiese germinado en el vientre, si no se hubiese implantado en él, ni pertenecido a quien posee ese vientre?” (De carne Christi 21). Sobre las ediciones de los textos de Tertuliano que utilizamos en este artículo, véase la nota 10. 
ción decisiva. La exaltación del vientre/útero de María ha sido directamente proporcional a la supresión de la placenta. Por esta razón, a lo largo de la tradición cristiana existen innumerables referencias al vientre de la Virgen, tanto en la Biblia como en los tratados de los Padres de la Iglesia, pero muy pocas - casi ninguna, al menos que nosotros sepamos-a la placenta. La placenta de María ha sido obliterada o excluida por el dogma cristológico. Dale Moody, por ejemplo, ha sostenido que el nacimiento de Jesús ha dejado de lado, en cierto sentido, el problema de la concepción: "el nacimiento de Jesús ha hecho olvidar la idea crucial de la concepción" (1953: 454); o también: "la concepción milagrosa de nuestro Señor es el punto, el punto crucial' (1953: 457; el subrayado es de Moody). John Wilkinson también ha indicado que el punto problemático se encuentra en la concepción: "Según su sentido teológico, la expresión [el nacimiento virginal de Cristo] mienta la concepción que precede al nacimiento más que al nacimiento mismo. El nacimiento, hasta dónde sabemos, fue normal, pero la concepción fue milagrosa" (1964: 160). El énfasis que se ha puesto en el nacimiento de Cristo, y el olvido consecuente del problema de la concepción, se explica en su sentido profundo por la dificultad ineludible que suponía abordar el problema de la placenta. Lo cual no significa que los Padres y teólogos no se hayan cuestionado acerca de la concepción milagrosa del Hijo de Dios. Muy por el contrario: cientos de textos han sido escritos sobre este problema a lo largo de la historia cristológica. Sin embargo, en casi todos los casos, las explicaciones han prescindido de la placenta. Las discusiones, en términos generales, han girado en torno a la posibilidad milagrosa de que la divinidad pudiera concebirse y gestarse en un vientre humano, pero nunca se han abordado las consecuencias de tamaño acontecimiento en relación a la placenta. Esta obliteración, por cierto, no es causal y obedece a diversas razones (teológicas, políticas, culturales, etc.). En este artículo nos proponemos ofrecer una explicación de los motivos filosóficos y teológicos que han fundamentado una cristología basada en la exaltación del vientre en detrimento de la placenta.

\section{EL VIENTRE Y LA PLACENTA}

En los Evangelios encontramos dos relatos, o más bien dos genealogías, acerca del nacimiento de Jesús. Por un lado, el linaje humano: Jesús desciende de David (eks spermatos David); por el otro, el linaje divino: Jesús es concebido por el Espíritu Santo (ek pneumatos hagiou). John W. Miller sostiene que el nacimiento virginal de Jesús no se encontraba originariamente en los Evangelios, sino que fue una interpolación posterior a partir del intento llevado adelante por Ignacio de Antioquía para unificar las dos grandes interpretaciones del nacimiento de Cristo: por un lado, quienes se 
basaban preferentemente en Pablo y consideraban a Jesús ek pneumatos hagiou; por otro lado, quienes se basaban en Mateo y consideraban a Jesús ek spermatos David. La epístola a los Efesios de Ignacio, en este punto, resulta decisiva: en ella el Hijo de Dios y el Hijo del hombre coinciden sin resto: "Bajo la divina dispensación Jesucristo nuestro Señor fue concebido por María de la semilla de David y del Espíritu de Dios" (citado en Miller, 2008: 122). Según Miller, la teología de Ignacio puede explicarse como el intento más extremo por sintetizar o unificar estas dos interpretaciones del nacimiento de Cristo, es decir por mostrar que el Salvador "desciende por un lado de la semilla de David y por el otro del Espíritu Santo" (2008: 122) $)^{8}$.

No nos interesa analizar aquí la validez o invalidez de la hipótesis de Miller, pero sí rescatar dos cuestiones esenciales: 1) el nacimiento virginal es el acontecimiento en el que lo divino (ek pneumatos hagiou) se une o entra en comunión con lo humano (ekspermatos David); 2) el vientre de María es el locus en el que tal comunión se lleva a cabo.

El dispositivo del nacimiento virginal, en este sentido, tiene como objetivo prioritario asegurar la conjunción de lo divino y lo humano. Philip Crannell, por ejemplo, en su artículo "The Supernatural Birth of (the) Christ", sostiene: "el nacimiento virginal proporciona una unión suficientemente completa y una identificación de lo divino y lo humano. Es la explicación más fácil y comprensible de la llegada al mundo del Hijo" (1932: 361)9. Interesa notar, como adelantamos, que ambos registros, humano y divino, encuentran su ocasión de comunión o convergencia en el vientre de María. El devenir carne del Verbo se produce en el vientre. Pero en tanto pertenece a María, el vientre corresponde siempre a la parte humana. En Tertuliano, por ejemplo, un autor preocupado por demostrar la realidad humana de la carne de Cristo, el vientre (volva) es sinónimo de humanidad, es lo que prueba, contra Marción, Valentino y los docetistas en general, que Cristo asumió una naturaleza carnal.

\footnotetext{
8 Según la hipótesis de Miller, las epístolas de Ignacio habrían servido como fuente de inspiración de los relatos acerca del nacimiento virginal de los Evangelios y no a la inversa: "El punto de partida de la teología de Ignacio no fueron los relatos del nacimiento virginal de Cristo de los Evangelios, sino que la teología de Ignacio fue el punto de partida de los relatos del Evangelio" (2008: 122).

9 También Allan Hoben indica que el nacimiento virginal permitió conjugar la divinidad y la humanidad de Cristo en una única persona: "Sobre las bases del nacimiento virginal los Padres pudieron probar tanto la divinidad cuanto la humanidad de Jesús, así como su falta de pecado, su función mediadora y la representación de una nueva raza en él, el nuevo Adán. Esto es verdad en Metodio, Lactancio, Arquelao, Malquión, Novaciano, Hipólito y en cierto sentido en todos los Padres a partir de Ignacio" (1908: 185).
} 
Si el Espíritu de Dios [dei spiritus] descendió en el vientre [descendit in vulvam] sin la intención de participar en la carne del vientre [de vulva carnem], ¿por qué descendió en el vientre? Porque podría haber sido hecho de carne espiritual fuera del útero con más facilidad que dentro de él. No había ningún propósito para dirigirse a un lugar del cual no se tomaría nada. Pero no fue casual que descendiera en el vientre. Por lo tanto, recibió algo de él. (De carne Christi $19.5)^{10}$

El caso de Tertuliano es interesante porque, como veremos en breve, hace referencia al cordón umbilical pero, en vez de conferirle a la placenta un estatus independiente e irreductible a la madre y al hijo, la identifica con los restos del vientre de María ${ }^{11}$. En primer lugar, Tertuliano cita algunos salmos de David y especifica, a partir de ellos, la importancia del útero de la Virgen para la gestación del Salvador. Uno de los salmos reza: "Porque eres tú quien me ha arrancado del útero de mi madre [avulsisti me ex utero matris meae]" (De carne Christi 20.4). Luego de lo cual argumenta:

¿Qué cosa se puede arrancar sino lo que se adhiere [quod inhaeret], lo que está plantado en profundidad [quod infixum], lo que está estrechamente ligado [quod innexum] a la cosa de la cual, al arrancarlo, se lo aparta? Si no estaba adherido al útero materno [adhaesit utero], ¿cómo puede haber sido arrancado? [...] ¿De qué modo, además, podía adherir, si, en el momento de salir del útero, no hubiese estado aún ligado a su matriz de origen a través del cordón umbilical [nervum umbilicarem], que era como la raíz que lo vinculaba al vientre [adnexus origini vulvae]? Cuando un cuerpo está unido a otro cuerpo, a él extraño [quid extraneum extraneo], la unión [adglutinatur] es tan íntima que los dos cuerpos forman, por así decir, una misma carne y las mismas vísceras [concarnatur et convisceratur]: a tal punto que, cuando un cuerpo es arrancado, lleva con sí los restos [sequelam] del cuerpo al cual estaba unido, que son como una prolongación de la unidad interrumpida [abruptae unitatis], y un vínculo de su mutua relación. (De carne Christi 20.5)

10 Respecto a los textos de Tertuliano, en este caso el De carne Christi, utilizamos las ediciones críticas de Sources Chrétiennes y la de Corpus Christianorum, vols. I-II, ambas consignadas en la bibliografía.

11 Muchos siglos después, Friedrich Hegel realizará la misma maniobra que Tertuliano y que gran parte de la onto-teo-logía de Occidente: el genio del niño en el vientre materno será identificado, no ya con la placenta, sino con la madre. En efecto, en la Enzyyklopädie, Hegel consigna: "La madre es el genio del niño ya que con esta palabra se suele entender la totalidad del espíritu afectado de mismidad en tanto ella existe para sí y constituye la sustancialidad subjetiva del otro que está puesto como individuo sólo de manera exterior; este último tiene solamente un ser-para-sí formal" (1986, \ 405: 125). Peter Sloterdijk hace referencia a este pasaje de Hegel y señala la identificación hegeliana entre genio y madre a la vez que la obliteración de la placenta (1998: 423). 
Es preciso prestar atención a los términos empleados por Tertuliano: el feto del Redentor se encuentra adherido (inhaesum), implantado (infixum) y ligado (innexum) al útero de María. Todas estas cualidades, inherentes a toda gestación humana, se cifran en última instancia en la acción de aglutinar o unir (adglutinare o simplemente glutinare). Descubrimos entonces que el objetivo del nacimiento virginal es el de aglutinar lo divino y lo humano, es decir producir una glutinatio, una unión o sutura entre ambos registros ${ }^{12}$. Tertuliano considera que el cordón umbilical (nervum umbilicaris) es una prueba de la íntima unión (glutinatio) que mantiene el feto con la madre. El cordón es como una raíz que conecta al feto con el vientre de la madre. A pesar de la asombrosa y precisa descripción de Tertuliano, la placenta queda relegada a un trasfondo opaco. Sólo se dice de ella que es un resto (sequela) de la madre, una suerte de desprendimiento del útero. Creemos que esta identificación de la placenta con la madre, esta reducción de la placenta al útero materno, no responde meramente al poco conocimiento ginecológico y biológico que existía en la época. Nuestra tesis es que por detrás de esta razón obvia se ocultaba un peligro mucho mayor y eminentemente teológico. A diferencia del útero y del vientre, que representaban la condición mediadora de Cristo, es decir el locus en el cual se efectuaba la unión de lo divino y lo humano, del Verbo y la carne, del arquetipo y la copia (Cristo como eikeon Theou, como imagen consubstancial al Padre) ${ }^{13}$, la placenta representaba una instancia intermedia pero irreductible a ambos

12 El verbo latino glutinare, en efecto, posee un sentido vinculado a la medicina según el cual designa la cicatrización o el sellado de una herida. Celso, por ejemplo, en De medicina 7.4, utiliza la expresión cicatricibus glutinandis.

13 Interpretamos la noción de eikoon, aplicada a Cristo, como "imagen consubstancial" al Padre en el sentido propuesto por el teólogo Vladimir Lossky: "Por la encarnación, que es el hecho dogmático fundamental del cristianismo, 'imagen' y 'teología' se encuentran ligadas de una manera tan estrecha que la expresión 'teología de la imagen' podría convertirse en un pleonasmo - por supuesto, si se quiere la teología como un conocimiento de Dios en su Logos que es la imagen consubstancial del Padre [la image consubstantielle du Père]" (1967: 131; el subrayado es nuestro); y también: "Puesto que el Logos de los cristianos es la imagen consubstancial del Padre, la relación de la imagen con el arquetipo (si se quiere conservar este último término, familiar a Orígenes, pero que debía ser ya un arcaísmo en Gregorio de Nisa), esta relación de la imagen con lo que manifiesta no podrá ser ya concebida como un participación (methexis) o un parentesco (syngeneia), pues se trata de identidad natural" (1967: 132); y, por último: "Cuando se quiere aplicar la teología de la imagen a la Trinidad sería necesario entonces, para evitar todo equívoco, hablar de 'imagen natural', como hacía Juan Damasceno, para quien el Hijo es un eikōn physiké 'completo, en todo semejante al Padre, salvo la inasibilidad y la paternidad"' (1967: 133). La misma idea, por otro lado, sugiere Hans Belting en relación a la querella de las imágenes: "En el Hijo del Hombre se hallaba la imagen original de Dios como en una reproducción" (2009: 206). 
términos. Ni humana ni divina, ni materna ni completamente fetal, la placenta ponía en cuestión el dogma de la encarnación y, más allá, la teología cristiana en su totalidad. Si el útero hacía posible el trabajo aglutinante de sutura efectuado por Cristo, la placenta, en cambio, realizaba un movimiento contrario de dehiscencia y de apertura de ambos registros metafísicos. ${ }^{14} \mathrm{Al}$ útero como locus coniunctionis se le opone la placenta como locus disiunctionis. En tanto irreductible a María y al Espíritu Santo, la condición de la placenta es eminentemente neutra (ne-uter. ni/ni). No pertenece a lo específicamente humano porque todos los mamíferos producen placentas; tampoco a lo divino, porque su realidad no pertenece exclusivamente al dominio puro y etéreo de la espiritualidad. El óvulo es propiedad de la madre, de María; el espermatozoide, del espíritu santo, de la divinidad. Philip Crannell, basándose en las Escrituras, sostiene que el Espíritu Santo aportó la parte masculina, es decir el esperma, mientras que María la parte femenina, el óvulo:

Debemos entender que el nacimiento virginal supone que el ser terrenal de nuestro Señor fue el producto de una intervención directa de la divinidad realizando la función, y mucho más que la función, del elemento masculino usual. Esta es la enseñanza indudable de las Escrituras. (1932: 349)

Pero si esto es así, la placenta debería haber poseído una naturaleza divina, eminentemente espiritual, puesto que son los genes masculinos los que la forman ${ }^{15}$. Se corría entonces el riesgo de que otro dios, menor quizás y definitivamente inhumano, compitiera con el Salvador. La concepción antigua de la placenta, en efecto, la consideraba una suerte de doble o alter ego del feto (una sombra, un fantasma, un espíritu o un demonio). Por eso mismo es preciso examinar rápidamente esta concepción pagana para comprender el peligro que representaba la placenta al interior de la cristología incipiente. A eso nos dedicaremos en el próximo apartado.

\section{El GEMELO FANTASMÁTICO DE CRISTO}

En diversas culturas de la Antigüedad, la placenta era venerada como un segundo yo o un doble de la persona. Foster de Witt, en un notable ensayo, sostiene que en diversas sociedades primitivas "la placenta era reconocida como un segundo niño, el doble" (1959: 235). Esta concepción animista afirmaba, en efecto, que la placenta era una suerte de gemelo de

\footnotetext{
14 Sobre las nociones de sutura y dehiscencia en relación al dispositivo cristológico, véase Prósperi, 2018: 67-80.

15 Sobre este punto, véase el apartado 3 de este artículo.
} 
la persona y que la relación entre ambos habitantes intrauterinos no resultaba interrumpida con el corte del cordón umbilical, sino que se prolongaba durante toda la vida. Como explica J. R. Davidson: "El factor operante en estas creencias era la concepción de que la placenta seguía unida durante toda la vida al niño con el cual había compartido el vientre materno" (1985: 75). Por tal razón, se la enterraba con sumo cuidado en un lugar específico para garantizar que no fuese comida por bestias salvajes. Los testimonios recogidos por Lucien Lévy-Bruhl en Le surnaturel et la nature dans la mentalité primitive resultan, en esta perspectiva, esclarecedores. El corte del cordón y el entierro de la placenta, correlativos al nacimiento del niño o niña, implicaba el tránsito a la vida de este último y el tránsito a la muerte de la placenta. Sin embargo, la placenta, lejos de desaparecer, subsistía como un espíritu o un fantasma, es decir como la sombra de un difunto.

Llega a este mundo con el recién nacido, del que es una suerte de gemelo. Pero hay más. Pasa pronto al mundo donde viven los muertos; en otros términos, deviene rápidamente un "espíritu". Bajo esta forma, acompaña y protege, hasta el fin de sus días, al niño que continúa viviendo sobre la tierra. Además, se identifica, sin confundirse, con él. (Lévy-Bruhl, 1931: 250)

En la medida en que el cordón y la placenta nacen junto con el niño o la niña, aunque sólo para morir y continuar viviendo como espíritus o fantasmas, explica Lévy-Bruhl, "se debe cuidar de su disposición, preocuparse por su bienestar, aportarles a veces ofrendas, etc." (1931: 252). Esta concepción antigua de la placenta como doble o alter ego fantasmático de la persona viviente posee un nexo indudable con la noción de $p s y c h e ̄ o ~ e i-$ dolōn que, según Erwin Rohde, caracterizaba al mundo homérico (Rohde, 1908: 1-36). En ambos casos, designa una suerte de Doppelgänger-subsistente más que existente- del hombre vivo. En ambos casos, además, los sueños representan la ocasión idónea para su encuentro y su comunión.

Dentro de esta concepción animista que las culturas primitivas tenían de la placenta, el caso de Egipto ocupa un lugar destacado. Como señala E. Croft Long: "Los egipcios antiguos creían en la dualidad de almas, una de las cuales habitaba en el individuo y la otra en la placenta" (1963: 239). En el Antiguo Egipto se creía que la placenta era la encarnación del alma externa en contraposición al alma corpórea, y que además contenía una parte del alma del niño, la cual sólo se liberaba si era tratada bien. El punto más alto de esta creencia concernía a la placenta del Faraón: "la placenta real - explica Foster de Witt- era transportada como un símbolo ante el Faraón, práctica que continuó hasta el tiempo de los Tolomeos (aprox. 325-45 a.C.)" (1959: 351). Resulta ilustrativo, en este sentido, el reverso de 
la famosa paleta de Narmer descubierta en 1898 por James Quibell y Green en el templo de Horus de Hieracómpolis (Nejen), actualmente depositada en el Museo Egipcio de El Cairo ${ }^{16}$.

C. G. Seligmann y Margaret A. Murray han demostrado que el estandarte llevado por el cuarto hombre contando de la derecha representa la placenta real: "el estandarte sobre la paleta y el cetro de Narmer representa la placenta" (1911: 171). Tanto por la morfología como por el color y el tamaño, es indudable que el objeto transportado por el hombre imberbe -los otros tres, cuyos estandartes son animales, tienen barba- es una placenta con su cordón umbilical. Esta procesión, que para nosotros puede resultar sorprendente, se explicaba perfectamente en función de las creencias del Antiguo Egipto: "en ciertas ocasiones -sostienen Murray y Seligmann- el cordón umbilical, representando la placenta, era transportado por un alto oficial, y también la placenta era considerada un gemelo del rey" (1911: 169).

Ahora bien, interesa notar, como ha mostrado Foster de Witt, que "en el Antiguo Testamento perdura la concepción animista de la placenta entendida como recipiente del alma del rey" (1959: 361). Y si bien es cierto que en todo el Antiguo Testamento encontramos una sola referencia directa a la placenta, cuando una madre se come los desechos del parto en tiempo de asedio (Deuteronomio 28:57), existe no obstante una referencia indirecta en 1 Samuel 25:29, tal como han mostrado Sir James Frazer y Margaret Murray. Se trata de las palabras que le dirige Abigail a David: "Bien que alguien se haya levantado a perseguirte y atentar contra tu vida, con todo, el alma de mi señor será ligada en el fajo de los que viven con Jehová tu Dios, y Él arrojará el alma de tus enemigos como de en medio de la palma de una honda". Según explica Frazer en el segundo volumen de su discutido Folklore in the Old Testament, las palabras pronunciadas por Abigail hacen referencia indirectamente a la creencia según la cual las almas de los vivos podían ser amarradas por seguridad en un fajo o haz de hojas, y que, por el contrario, cuando se trataba de las almas de los enemigos, el fajo podía ser desatado y las almas diluidas en el viento. Estas costumbres de los pueblos primitivos, al igual que la adivinación, la necromancia o la idolatría, son duramente condenadas por la religión hebrea. Sin embargo, justamente por eso, Frazer afirma que no era para nada desconocida por los autores veterotestamentarios:

16 Véase: https://www.wikizeroo.org/index.php?q=aHR0cHM6Ly91cGxvYWQud2lraW1lZGlhLm9yZy93aWtpcGVkaWEvY29tbW9ucy91L2U3L05hcm1lc19QYWxldHRIX3NlcnBvcGFyZF9zaWRILmpwZw 
Los hebreos aparentemente retenían desde tiempos antiguos la concepción del alma como algo separable que puede ser extraído del cuerpo del ser humano durante su vida, ya sea a través del arte maligno de las brujas, ya sea por un acto voluntario de la propia persona, a fin de depositarla por mayor o menor tiempo en un lugar seguro. (1919: 513)

Margaret Murray, por su parte, ha demostrado con gran contundencia que el "fajo de vida" de 1 Samuel 25:29 hace referencia a la costumbre egipcia de envolver la placenta real en un atado sagrado que resultaba determinante para la salud y el destino del rey ${ }^{17}$. Si esto es así, si el culto a la placenta, frecuente en diversas culturas de la Antigüedad, no era desconocido por los hebreos, es más que factible que tampoco haya sido desconocido por los autores neotestamentarios y por los Padres apologéticos. ${ }^{18}$ Comenzamos a comprender así el peligro que se escondía en la figura de la placenta en relación a Cristo, sobre todo si se tiene en cuenta la influencia egipcia. En efecto, como ha mostrado Michael Rice, la placenta no era sólo un doble o un alter ego del Faraón, sino que además el Faraón ocupaba el mismo lugar mediador entre los dioses y los hombres que Cristo.

En tanto gemelo, [la placenta] coexistía eternamente con el rey de tal manera que el rey mismo era, en el instante de su nacimiento, dos entidades indivisibles [...] El rey era el nexo entre el mundo de los dioses y el mundo de los hombres, existiendo igualmente y eternamente en ambos. Todos sus títulos eran duales; él era, en este sentido, su propio gemelo. (Rice, 2004: 108-109)

Reconocer la placenta de Cristo, a la luz de estas costumbres paganas, hubiese significado admitir que el Salvador tenía un gemelo o un doble, una suerte de alter ego fantasmático ${ }^{19}$. A diferencia del vientre o del útero,

17 Sobre la relación del pasaje de 1 Samuel 25:29 y la concepción egipcia de la placenta real, véase Murray, 1930: 65-73. Sobre el culto egipcio de la placenta, véase Rice, 2004: 108-110.

18 Como se sabe, la influencia de la religión egipcia sobre el cristianismo está más allá de toda duda. Sobre este punto, véase Osman, 2005; Bargeman, 2005. Esta última autora, además, indica con vehemencia la importancia de la religión egipcia en el catolicismo romano: "Si bien todas las formas del cristianismo evidencian fuertes paralelos con los rituales del Antiguo Egipto, quizás los mayores ejemplos pueden ser discernidos en el catolicismo romano" (Bargeman, 2005: 1).

19 Es interesante señalar que la teología política del cristianismo ha utilizado la expresión gemina persona para referirse a las dos naturalezas de la segunda hipóstasis y, como un reflejo de ellas, a la condición también dual del rey o monarca. Ernst Kantorowicz, por ejemplo, retomando una fuerte tradición medieval, se refiere al Christus y al rey terrenal, al vicarius Christi, como un "ser gemelo o mellizo [twinned being]" o como una "personalidad melliza [twin personality]": "Él, el ungido por gracia [es decir el rey], reproducía como una gemina persona la doble naturaleza de Cristo. Es la idea medieval de 
la placenta poseía una carga indudablemente peligrosa para los pilares cristológicos. Por eso el nacimiento virginal de Cristo exalta el vientre de María a la vez que, en un mismo movimiento, prescinde de la placenta. Y cuando es mencionada, como en el caso de Tertuliano, se le quita todo rasgo semi o seudo-divino, reduciéndola a un mero resto (sequela) humano. La posibilidad de introducir una dualidad en Cristo, un gemelo o doble, era ciertamente aberrante. La tradición cristológica, sin embargo, conoce este alter ego del Redentor: su nombre es antichristos. El vientre es a Cristo lo que la placenta es al Anticristo. De tal modo que, si el vientre funciona como locus coniunctionis, la placenta lo hace como locus disiunctionis. Cristo, en tanto mediador, es el sym-bolon, quien mantiene acoplados o aglutinados el mundo divino y el mundo humano; el Anticristo, en cambio, es el diabolon, quien separa los reinos, al modo de una dehiscencia, sin identificarse con ninguno de ellos ${ }^{20}$. El lugar que resta, una vez abiertas las paredes cuya contigüidad sin fisura asegura - o pretende asegurar - la unión hipostática de la naturaleza divina con la naturaleza humana, el lugar irreductible a cualquiera de las dos naturalezas, tanto a la divinidad del Espíritu Santo cuanto a la humanidad de la Virgen Madre, es la placenta.

una realeza centrada en Cristo llevada a un extremo no tan fácil de encontrar en el Occidente. El rey es un ser mellizo [a twinned being], humano y divino, al igual que el Dioshombre, aunque el rey posee una doble naturaleza y es gemelo por gracia y en el tiempo, y no por naturaleza y (después del Ascenso) en la eternidad: el rey terrenal no es, sino que deviene una personalidad melliza a través de su unción y consagración. La expresión misma, gemina persona, no representa una metáfora poética, sino que es un término técnico derivado de y relacionado con las definiciones cristológicas" (1957: 49). No obstante, Kantorowicz advierte rápidamente el peligro de postular dos personas, peligro que la propia teología, so pena de incurrir en la herejía nestoriana o adopcionista, se había encargado oportunamente de conjurar: "De acuerdo al dogma ortodoxo, Cristo es una persona, duae naturae. "Persona gemela", por lo tanto, era una expresión que debía evitarse por ser dogmáticamente peligrosa; era tan mala como "dos personas", ya que dejaba abierta la posibilidad de una interpretación nestoriana o adopcionista" (1957:49). Por eso mismo, a causa de este riesgo evidente, las discusiones se mantenían dentro de los parámetros metafísicos aceptados por la onto-teo-logía: humanidad y divinidad, materia y espíritu, cuerpo y alma, etc. La confusión de estos términos era ciertamente peligrosa, pero el mayor riesgo, en tanto se sustraía a los parámetros admitidos por la teología dogmática, era la posibilidad de un doble fantasmático - es decir, ni humano ni divino, ni material ni espiritual- de Cristo. La noción de gemelo que surgía de las creencias del paganismo antiguo en relación a la placenta remitía precisamente a este doble extraño y extranjero, demoníaco e irreductible, de la persona nacida; en este caso, de Cristo.

20 Para un panorama general de la etimología y el significado de los términos symbolon y diabolon, véase las entradas $\sigma \dot{\mu} \mu \beta o \lambda o v$ y $\delta i \dot{\alpha} \beta o \lambda o \varsigma$ respectivamente en el Liddell-Scott Greek Lexicon [En línea: http://www.perseus.tufts.edu/hopper/resolveform?redirect=true]. Para más detalles sobre el término symbolon, véase Alleau, 1958; sobre diabolon, véase Wray \& Mobley, 2005: 24-25; Forsyth, 1987: 4. 


\section{3. ¿TRASPLANTE, CÁNCER O PARÁSITO?}

Por curioso que parezca, si consideramos el nacimiento virginal de Cristo desde una perspectiva biológica actual, descubrimos que el riesgo que representa la placenta para la teología es igualmente -O acaso aún más- considerable. No deja de ser llamativo, además, que la placenta sea el órgano encargado de mediar entre el feto y la madre. En este sentido, Y. W. Loke ha podido sostener, en un texto notable, que "ningún otro órgano en el cuerpo es capaz de desarrollar este tipo de función dual" (2013: 7); o también, para citar a Michael Power, que la placenta funciona "como el órgano central de un sistema bidireccional" (2005: 29)21. La placenta extrae nutrientes y oxígeno de la sangre materna y la envía al feto, a la vez que transporta desechos y dióxido de carbono en sentido contrario. Pero el punto más interesante es que la placenta es de algún modo ajena tanto al feto, con el cual comparte sin embargo la misma carga genética, cuanto a la madre, a la cual se adhiere hasta penetrar en sus vasos sanguíneos. En este sentido, "este órgano intrigante y misterioso" (Parolini, 2016: ix) es externo e irreductible tanto al feto cuanto a la madre: "la placenta pasa toda su vida fuera del bebé pero dentro de otro individuo, la madre, a cuyo útero está íntimamente ligada" (Loke, 2013: 5). La placenta funciona así como una membrana bidireccional: por un lado, se adhiere a la pared del útero materno conocida como desidua; por otro, se conecta con el feto a través del cordón umbilical. Según Loke, la placenta ocupa una suerte de tierra de nadie entre la madre y el feto:

el bebé no está adherido a la pared uterina, a pesar de ocupar mucho espacio dentro del útero. [...] Es la placenta la que conecta al bebé con la madre en el lugar de la implantación [...] La placenta se ubica entremedio [in between]. La naturaleza es sabia al disponer a la placenta fuera del bebé. En el útero, la placenta ocupa una posición a medio camino entre [midway between] el bebé y la madre, en una suerte de tierra de nadie [no-man's land]. (2013: 6)

Una vez que el espermatozoide fecunda al óvulo se forma el blastocito, el cual se divide a su vez en dos conjuntos de células: embrionales y

21 No es casual, en este sentido, que Jacques Lacan considere, en la sesión del 6 de marzo del famoso seminario X sobre la angustia, que la placenta (y el seno materno) son "elementos que podemos calificar de amboceptores" (2006: 181). En efecto, continúa Lacan, “¿de qué lado está el seno? ¿del lado del que chupa, o del lado del que es chupado?" (2006: 181). La referencia a la placenta le sirve a Lacan para mostrar el carácter amboceptor del objeto a, el cual, como se sabe, se produce por efecto de un corte. Sobre la concepción lacaniana de la placenta, véase también la sesión del 15 de Mayo de 1963 del seminario $\mathrm{X}$. 
extra-embrionales. Las células embrionales, agrupadas en el centro, se convertirán en el feto propiamente dicho; las extra-embrionales formarán la placenta. El primer paso de este segundo grupo de células consiste en formar una capa o película conocida como trofoblasto a fin de rodear el núcleo central donde se constituirá el embrión. Es interesante notar que aproximadamente el 80 por ciento de las células formadas son extra-embrionales, lo cual demuestra que la creación de la placenta es aún más fundamental que la del embrión. A partir de esta separación celular, la placenta prosigue y organiza su propio programa de desarrollo, con total independencia del embrión (Loke, 2013: 9). Las células embrionales y las extraembrionales, a pesar de provenir del mismo óvulo fecundado, poseen características y funciones diferentes.

Como hemos visto, tanto el espermatozoide como el óvulo son necesarios para la formación de la placenta y del embrión. Por tal razón, el fenómeno conocido como partenogénesis, es decir la forma de reproducción basada en el desarrollo de células sexuales femeninas no fecundadas, es imposible en los mamíferos. No deja de ser curioso que Loke mencione como un ejemplo de partenogénesis el nacimiento virginal de Cristo (al cual denomina, erróneamente, inmaculada concepción):

El ejemplo citado con más frecuencia como la excepción a la regla es la inmaculada concepción de la Virgen María, porque ella misma confesó, “¿cómo puede ser si no he estado con ningún hombre?”. Además, Jesús es varón y resulta difícil explicar cómo podría haber surgido de una concepción partenogenética ya que los óvulos sólo tienen el cromosoma $\mathrm{X}$ femenino. (2013: 10)

Sin embargo, John Wilkinson sostiene que el nacimiento virginal debe ser disociado "por completo del fenómeno considerado como partenogénesis" (1964: 160). ¿Por qué? Philip Crannell, en un pasaje ya citado, lo explica a la perfección: "nuestro Señor fue el producto de una intervención directa de la divinidad realizando la función, y mucho más que la función, del elemento masculino usual" (1932: 349). De tal manera que el elemento masculino fue aportado por el Espíritu Santo. Pero si esto es así, la placenta habría debido poseer una naturaleza divina, eminentemente espiritual, puesto que su composición genética proviene del aporte masculino. La realidad carnal -por no decir sórdida- de la placenta, sin embargo, demuestra su materialidad. ¿Dónde ubicar entonces a este órgano enigmático? ¿Bajo qué categoría teológica subsumirlo? ¿Qué región de la ontoteo-logía le haría justicia? El dominio humano no, porque la placenta no posee conciencia ni razón (aspectos distintivos, para la tradición metafísica, de lo humano) y porque también los animales (mamíferos) requieren 
de la placenta; el dominio divino tampoco, porque su naturaleza no posee la inmaterialidad del espíritu, y si la posee, como en el caso del doble o el yo invisible de las culturas antiguas, está más vinculada a lo que podríamos llamar una "baja divinidad" o un "animismo menor" que a la trascendencia intangible del Dios bíblico. Como indica Loke, la placenta subsiste en una no man's land que no sólo es la tierra de nadie, sino también -y de manera fundamental- la tierra de no-man, de lo no-humano. Esta topología an-humana, sin embargo, no debe ser confundida con el Dios-Padre de las Escrituras. Así como es una no man's land, es también una no God's land. Ni humana ni divina, la placenta es la cifra del mundo de las imágenes. De allí su vínculo con los sueños y la muerte. Como la psychè, el eidolōn o el phantasma de los tiempos homéricos, la placenta es el locus específico en el que proliferan las imágenes, irreductibles a las grandes polaridades de la ontoteo-logía: lo sensible y lo inteligible, la materia y el espíritu, lo visible y lo invisible, etc. ${ }^{22}$.

Pero ¿qué es, después de todo, la placenta? "La placenta humana es muchas cosas diferentes en un solo órgano que desafía la clasificación biológica convencional. ¿Es un trasplante, un cáncer, un parásito? Tiene características de todas estas cosas" (Loke, 2013: 223). La placenta es el abismo entre Dios y el hombre, entre la carne y el espíritu (en su sentido bíblico): el pliegue intermedio, pero irreductible, entre el esperma del Espíritu Santo y el óvulo de María; en verdad es la dehiscencia al interior del

22 Cuando hablamos de "onto-teo-logía" nos situamos por supuesto en la línea abierta por Martin Heidegger y retomada posteriormente por Jacques Derrida y Giorgio Agamben entre otros. En efecto, para Heidegger la metafísica comienza con Platón y culmina con Nietzsche (véase Heidegger, 1997: 235; 1961: 525). Se objetará que se trata de una concepción demasiado general de la historia, alejada de la minuciosidad de un artículo académico. Sin embargo, nuestro objetivo no es discutir dicha concepción de la historia occidental, sino adoptarla como marco general para inscribir allí la tradición cristológica. Por tal razón, a pesar de las innumerables objeciones que esta aproximación filosófica de la historia ha suscitado, nos sigue resultando provechosa y extremadamente rica a la hora de crear instrumentos de pensamiento. Hacemos nuestras, en este sentido, las palabras que Marcel Gauchet escribía en su texto dedicado a la bistoire politique de la religion: "no desconocemos los peligros de la empresa y las incertidumbres inherentes a una visión caballeresca de la historia universal. No ignoramos de ninguna manera que las cosas son 'más complicadas' que como las presentamos, concebimos la desconfianza frente al género 'filosofía de la historia', hemos oído hablar de los equívocos de los 'pensamientos de la totalidad'. Los riesgos son tomados con conciencia, sin otra intención que la necesidad de comprender, y con la firme convicción no sólo de que vale la pena arriesgarse, sino de que no es posible no hacerlo. No es ceder a las sirenas de la especulación, es obedecer de manera crítica a una exigencia de sentido frente a la cual, los que se creen ingenuamente victoriosos, son quienes menos la han superado" (1985: xxi). ¿Ironía del dispositivo histórico: nos hace creer que en su superación reside nuestra liberación? 
pliegue. Si en Cristo, en el embrión, la divinidad (espiritual) del Padre se une con la humanidad (carnal) de la madre, en la placenta se desunen, y lo que resta en ese espacio an-antrópico y a-teológico es la imagen, el fantasma: ho antichristos. ¿Por qué el Anticristo es el nombre "propio" de la placenta? Porque no es lo otro de Cristo -sabemos, de hecho, que la relación entre la placenta y el feto es esencial- sino su otro lado ${ }^{23}$; no es el antagonista radical y maligno sino su otro yo o, mejor aún, el otro lado del yo, el otro lado que ya no es un yo $^{24}$. Es un trasplante, un cáncer y un parásito.

\section{Plegaria PARA UN ÓRGANO DORMIDO}

El individualismo burgués de la época moderna, según la tesis de Peter Sloterdijk, es el resultado ineluctable de una "desvalorización radical de la placenta" (1998: 386). Y si bien a lo largo de la historia existen varios momentos de "nihilismo placentario [plazentaler Nibilismus]" (1998: 391), es recién en el siglo XVIII que el destierro de la placenta del imaginario social alcanza su punto crítico: "Sería fácil demostrar que el individualismo moderno sólo pudo entrar en su fase álgida cuando en la segunda mitad del siglo XVIII comenzó la general excomunión clínica y cultural de la placenta" (1998: 388). Además de esta excomunión moderna de la placenta, Sloterdijk señala que la medicina helenista impulsó también, aunque en menor medida, un desencanto del fenómeno placentario.

Para referirse a la placenta y al embrión sin caer en los presupuestos propios de la tradición occidental, Sloterdijk utiliza los términos "con" y "también" respectivamente: "al órgano con el que el presujeto flota en su cueva comunicándose [...] le llamaremos el 'con' [das Mit]” (1998: 360); al

23 Cuando decimos que el Anticristo no es lo otro de Cristo, sino su otro lado, tenemos presente un pasaje de Le visible et l'invisible en el que Merleau-Ponty explica la relación entre el cuerpo y el espíritu. Luego de afirmar que "hay un cuerpo del espíritu, y un espíritu del cuerpo y un quiasmo entre ellos" (1964: 307), Merleau-Ponty sostiene: "El 'otro lado' quiere decir que el cuerpo, en tanto que tiene este otro lado, no es descriptible en términos objetivos, en términos de sí, -que este otro lado es verdaderamente el otro lado del cuerpo, desborda en él (Ueberschreiten), se solapa sobre él, está oculto en él, - y al mismo tiempo tiene necesidad de él, se termina en él, se ancla en él" (1964: 307). De la misma manera, el Anticristo no designa lo otro absoluto de Cristo, sino una suerte de solapamiento o desborde del mismo Cristo. Cristo y Anticristo, así, son como el reverso y el derecho de la segunda bypostasis.

24 Para explicar esta relación extremadamente paradójica entre Cristo y el Anticristo sería preciso citar las palabras que utiliza Michel Foucault, en su ensayo sobre Pierre Klossowski, cuando explica que el Demonio, en relación a Dios, no es "la Antítesis sin escapatoria (o casi), la mala materia, sino más bien algo extraño, desconcertante que se queda quieto y sin moverse del sitio: el Mismo, el exactamente Semejante” (2001: 326). 
feto, por su parte, “debería llamársele el 'también' [das Auch], ya que esa identidad fetal sólo se produce por la vuelta del con, que es-ahí, al aquí, que es 'también aquí' [auch-bier]" (1998: 360). La excomunión clínica y cultural de la placenta propia del mundo burgués, ya anunciada en cierto sentido por la medicina helenista, implica un olvido de este espacio bipolar intrauterino conformado por la estructura con-también. Lo que Sloterdijk no dice, pero que nosotros creemos decisivo, es que el nacimiento del Redentor representa un caso paradigmático de este proceso de desvalorización radical de la placenta. El nacimiento virginal de Cristo es el dispositivo elaborado por la teología cristiana para conjurar la placenta y, con ella, toda forma de dualidad o polaridad anímica. Pero por eso mismo, la ekelesia, entendida como comunidad de fieles, se construyó a partir del nexo (de la glutinatio) entre lo divino y lo humano propiciado por Cristo en el vientre de María. Esta comunidad eclesiástica, para constituirse, se vio forzada a suprimir la placenta, el doble o el gemelo inasimilable, la sombra irreductible: el Anticristo. ¿Por qué inasimilable e irreductible? Porque no es ni persona ni sujeto, ni substancia ni objeto y, por ende, no pertenece al dominio de la presencia: "Por lo que se refiere al con, según su cualidad de presente, no es ni persona ni sujeto, sino un ello viviente y vivificante, que se mantiene ahí-en-la-proximidad" (Sloterdijk, 1998: 360).

No deja de ser llamativo que conservemos, pese a todo, el estigma o la cicatriz de esa convivencia o comunidad prenatal: el ombligo. Por eso Sloterdijk puede afirmar que para pensar la placenta y restituirle sus derechos obliterados, debemos "primero descifrar el jeroglífico del ombligo [die Hieroglyphe den Nabel]" (1998: 395). El corte del cordón es, en este sentido, el acontecimiento fundamental que marca la entrada del sujeto en lo simbólico, es decir la entrada en el sujeto ${ }^{25}$. El corte del cordón en la Modernidad, lejos de simbolizar, como en las culturas primitivas, la muerte de la placenta y su consecuente vida post-mortem, marca la condición autosuficiente y hermética del sujeto burgués normal. Sin embargo, el ombligo nos recuerda que en un tiempo nuestra vida dependió literalmente de un otro, de un "órgano-ángel [Organ-Engel]" (1998: 362), una "sombra nutricia y hermano anónimo" (1998: 360); nos recuerda, en suma, que no existiríamos si no hubiese sido por "ese misérrimo fantasma de la ópera de las entrañas" (1998: 362).

No sorprenderá que los Evangelios hagan referencia a la circuncisión de Cristo, al corte del prepucio, pero no al corte del cordón ${ }^{26}$. A diferencia

25 Utilizamos la noción de "simbólico", aquí, en el sentido lacaniano. Sobre este punto, véase Juignet, 2003: 131-144.

26 Sobre la circuncisión de Cristo, véase Jacobs, 2012. Sobre la circuncisión en la cultura hebrea, véase Glick, 2005. 
del praeputium, que representa la Ley judía, el símbolo de la alianza, es decir de la unión de Dios y los hombres, el umbilicus representa la condición incompleta o la apertura que ninguna persona, ni humana ni divina, puede suturar. El umbilicus, de algún modo, es la marca de la imposibilidad de lo divino y lo humano ${ }^{27}$. No es casual que Luce Irigaray contraponga el cordón umbilical a la figura del falo: "¿El falo erigiéndose en el lugar que antes ocupaba el cordón umbilical?” (1994: 37)28. Y también: "Y cuando se le da apellido a la criatura, éste ya viene a ocupar el lugar de la señal más irreductible del nacimiento, el ombligo. El apellido e incluso ya el nombre de pila siempre se hallan desfasados respecto al más irreductible rastro de identidad: la cicatriz del corte del cordón" (1994: 37). En el caso de Cristo, es sintomático que el nombre Jesús le es consignado, no con el corte del cordón, sino con la circuncisión. En este sentido, la circuncisión viene a clausurar u obliterar el corte del cordón: "En el lugar que ocupaba el cordón, aparecería el pene que une, da vida, abreva, alimenta y recentra al cuerpo recordando, en la eyaculación y la detumescencia, la efusión y la cicatriz original que marcan el paso de la vida intrauterina al nacimiento, para el hombre y para la mujer" (1994: 40).

El umbilicus es la llaga que se abre entre lo divino y lo humano, entre lo invisible y lo visible o entre el espíritu y la materia. La cristología, desde su inicio, supone una alienación fundamental: en el vientre de María, el feto del Salvador dependió de un alius extraño y extranjero, un elemento inasimilable en la economía de la salvación. El doble de Cristo, el otro de Cristo, el otro lado de Cristo, el alios Christos, el alien, el Cristo extranjero: nombres todos del anti-Cristo. No obstante, se trata de una alienación diversa a la hegeliana (o marxista). No es que el uno devenga dos ni que el uno y el dos se reconcilien en el tres. Más bien habría que decir que feto y placenta son las dos caras o los dos polos de una estructura diádica sin resolución; al extremo, el uno, el feto-Cristo, depende del dos, de la placenta-Anticristo. A la economía soteriológica del dogma se le opone la “economía placentaria” (Irigaray, 1993: 37-44)29.

La preeminencia ontológica del prepucio, presente en los relatos de la natividad de Jesús, hunde sus raíces en la cultura hebrea. No es casual que en el Antiguo Egipto la placenta gozara de mayor jerarquía que el prepucio y que el corte del cordón fuese considerado más determinante para la vida

27 Consigna Sloterdijk: "El ombligo está en el lado delantero del ser humano como un monumento en recuerdo de lo impensable; recuerda aquello de lo cual nadie se acuerda. Es el signo puro de lo que para la conciencia queda al otro lado de lo cognoscible" (1998: 455). De la misma manera, lo que queda al otro lado de Cristo es el Anticristo.

28 Sobre la relación entre el falo, el ombligo y la muerte desde una perspectiva feminista, véase Bronfen, 1992: 145-158.

29 Sobre la noción de economía placentaria en Irigaray, véase Bollinger, 2007: 325-352. 
del individuo que la circuncisión: "Ninguna otra parte de la anatomía real parece haber gozado del mismo cuidado y reverencia que la placenta. Ni siquiera al prepucio real le fue acordado un honor comparable. Además, la circuncisión no parece haber sido una práctica frecuente en los tiempos antiguos" (Rice, 2004: 108).

\section{CONCLUSIÓN}

El nacimiento virginal de Cristo se ha constituido en su forma dogmática a partir de la obliteración de la placenta. El vientre, y más concretamente el útero, de María, en este sentido, ha sido el locus simbólico de la encarnación, es decir el lugar en el que lo divino, el Espíritu Santo, ha podido unirse o aglutinarse con lo humano. Para poder salvaguardar esta coniunctio o glutinatio, sin embargo, la cristología se vio obligada a excomulgar la placenta de los relatos sobre el nacimiento del Salvador. Las menciones a ella son ciertamente exiguas e indirectas si se las compara con las que se refieren al vientre de la Virgen. Hemos mostrado que la razón profunda de esta exclusión no es casual, sino que obedece a motivos eminentemente teológicos y a concepciones antiguas vinculadas a lo sagrado y sobrenatural. Como hemos indicado, las culturas primitivas consideraban a la placenta un doble o un gemelo de la persona, razón por la cual se la veneraba y temía. Lejos de ser desechada en el momento del nacimiento, la placenta era enterrada en un lugar apropiado, a veces colgada de un árbol, para que el doble fantasmático o el alma invisible acompañase y cuidase al recién nacido durante toda su vida. El nacimiento del niño o niña, así, implicaba la muerte de la placenta pero, por eso mismo, el inicio de su vida post-mortem, de su subsistencia fantasmática.

Se advertirá el peligro que representaba una concepción semejante para la cristología dogmática. Enfatizar el rol de la placenta, por otro lado necesario para la consecución de un nacimiento exitoso, a la luz de estas creencias paganas, conocidas además por los hebreos y los autores neotestamentarios, abría la puerta a la posibilidad de que el Redentor poseyese un doble o un gemelo, un otro extraño e irreductible. Ante este riesgo, la maniobra implementada por la teología consistió en reducir la placenta a su costado humano, identificándola simplemente con un resto o secuela del vientre de la Virgen. De ocupar un lugar intermedio entre la trascendencia divina y la inmanencia humana, la placenta fue desplazada al polo material de los desechos postparto.

Nosotros, por el contrario, hemos querido avanzar en este camino obturado por la cristología dogmática. Así como el vientre es el símbolo de la coniunctio metafísica, la placenta lo es de la disiunctio. Hemos identificado, además, a este otro de Cristo o, más bien, a este otro lado de Cristo, 
a este gemelo o doble, con el Anticristo. De tal manera que el Anticristo no designa para nosotros el rival humano y el mero antagonista del Salvador sino su costado fantasmático, su doble que es el mismo Cristo, pero el mismo en tanto otro. Siendo irreductible tanto al feto cuanto a la madre, la placenta, entendida como Anticristo, es ajena a la materia y al espíritu, a lo divino y a lo humano. En este sentido, no designa meramente el órgano indispensable para la vida del feto sino la cifra o el símbolo del reino de las imágenes. ¿Por qué? Porque las imágenes, y consecuentemente la imaginación, han ocupado el lugar intermedio entre las grandes polaridades de la onto-teo-logía: lo sensible y lo inteligible, la materia y el espíritu, el alma y el cuerpo, etc. ${ }^{30}$. Pero mientras que Cristo, en tanto eikōn Theou, ha funcionado como mediador, como locus coniunctionis, es decir como puente entre Dios y los hombres, el Anticristo, en tanto phantasma Theou, ha funcionado como locus disiunctionis, es decir como dehiscencia y disyunción ${ }^{31}$.

30 Podríamos citar innumerables ejemplos que apoyan este lugar intermedio de la imaginación en relación a lo sensible y lo inteligible. Lodi Nauta y Detlev Pätzold, sin ir más lejos, sostienen desde una perspectiva psicológica: "En tanto facultad del alma [la imaginación] se caracteriza en las teorías filosóficas, psicológicas y médicas por ser la mediadora entre los sentidos y la razón" (2004: ix). John Cocking, por su parte, escribe: "en la tradición filosófica que surge de Aristóteles, la fantasía es el nexo entre la sensación y el espíritu, y en la teología de la emanación es el nexo en el proceso contrario; el espíritu divino, creando, pasa de la pura inteligencia a la substancia sensible a través de la imaginación" (1991: 31). En una misma perspectiva, John Lyons se refiere a la imaginación como "la forma de pensamiento que media entre el cuerpo y el intelecto" (2005: xiii). Jan Veenstra expresa la misma idea: "Es una facultad intermedia entre los sentidos y la intelección, siguiendo a los primeros y precediendo a la última, una facultad entre lo corpóreo y lo incorpóreo" (2004: 14). Luigi Ambrosi también enfatiza la "extraña mezcolanza de su naturaleza a un tiempo material y espiritual" (1898: xxx). Giorgio Agamben, por último, refiere: "La imaginación recibe así un rango decisivo en todos los sentidos: en el vértice del alma individual, en el límite entre lo corpóreo y lo incorpóreo, lo individual y lo común, la sensación y el pensamiento, representa el residuo último que la combustión de la existencia individual abandona en el umbral de lo separado y de lo eterno. En este sentido, la imaginación -y no el intelecto - es el principio definitorio de la especie humana" (2007: 51-52); y también, un poco más tarde: "es en la imaginación donde tiene lugar la fractura entre lo individual y lo impersonal, lo múltiple y lo único, lo sensible y lo inteligible y, a la vez, la tarea de su dialéctica recomposición” (2007: 56).

31 Es preciso indicar que la distinción entre eikón y phantasma, en el sentido que le damos aquí, proviene directamente de la lectura que realiza Gilles Deleuze de Platón en el ensayo "Platon et le simulacre". En efecto, allí Deleuze sostiene que la verdadera distinción del platonismo no radica en la dicotomía modelo-copia o Idea-imagen, sino entre dos tipos de imágenes: las copias-íconos, dotadas de semejanza y fundadas en las Formas o esencias; los simulacros-fantasmas, repeticiones infundadas de una desemejanza o disparidad. Estos últimos designan una imagen sin semejanza, es decir, una imagen que se ha eximido, por así decir, de su relación con un modelo. Ni copia ni arquetipo, el fantasma es una intensidad diferencial: "Partíamos de una primera determi- 
La placenta, por eso mismo, no designa ni el reino humano ni el reino divino, sino el espacio neutro que se abre entremedio.

La historia de la pintura, como se sabe, está repleta de alusiones al nacimiento virginal de Cristo. El motivo Madonna con niño, en este sentido, es harto frecuente y constituye una de las imágenes icónicas de la cristiandad. La mayor parte de estas obras destacan la relación madre-hijo y la consecuente humanidad del Redentor. Frente a esta tradición canónica, quisiéramos mencionar, como corolario de nuestro recorrido, la obra One Flesh (1985) de la artista inglesa Helen Chadwick ${ }^{32}$. Esta obra -que, según aclara Leila McKellar, efectúa una verdadera "disrupción de las categorías binarias" (2007: 204) - se basa en la iconografía religiosa tradicional, pero sólo para subvertirla por completo. En efecto, en primer lugar, no se trata de un niño sino de una niña; en segundo lugar, la mano derecha de la madre está apuntando a los genitales de la recién nacida; en tercer lugar, la mano izquierda sostiene unas tijeras con las que se dispone a cortar el cordón umbilical; en cuarto y último lugar, por encima de la madre (y de la niña) flota, a la manera de un halo o aura, la placenta. Según explica McKellar: "La subversión de Chadwick se vuelve evidente en el halo dorado sobre las figuras, que a una inspección más minuciosa revela ser una placenta" (2007: 203). Madre, niña y placenta constituyen una suerte de "trinidad biológica" (citado en Herles, 1997). Lo que nos interesa de esta obra, en función del tema que hemos desarrollado en este artículo, es el lugar determinante que ocupa la placenta en relación al imaginario vinculado al nacimiento virginal. Chadwick muestra la condición irreductible de la placenta: externa al feto o a la niña y externa también a la madre. El corte del

nación del motivo platónico: distinguir la esencia y la apariencia, lo inteligible y lo sensible, la Idea y la imagen, el original y la copia, el modelo y el simulacro. Pero ya vemos que estas expresiones no son válidas. La distinción se desplaza entre dos tipos de imágenes. Las copias son poseedoras de segunda, pretendientes bien fundados, garantizados por la semejanza; los simulacros están, como los falsos pretendientes, construidos sobre una disimilitud, y poseen una perversión y una desviación esenciales" (Deleuze, 1969: 295296). Interesa destacar que, para Deleuze, entre el eikōn y el phantasma existe una diferencia de naturaleza: "Si decimos del simulacro que es una copia de una copia, ícono infinitamente degradado, una semejanza infinitamente disminuida, dejamos de lado lo esencial: la diferencia de naturaleza entre simulacro y copia, el aspecto por el cual ellos forman las dos mitades de una división. La copia es una imagen dotada de semejanza, el simulacro una imagen sin semejanza" (1969: 297). En este sentido podemos afirmar que, en tanto phantasma, el Anticristo niega a la vez al Padre (archetypos) y al Hijo (eikōn). Por eso Juan, en su primera epístola, puede afirmar: "¿Quién es mentiroso, sino el que niega que Jesús es el Cristo? Éste es el anticristo [ho antichristos], que niega al Padre y al Hijo" (1 Juan 2:22). 32 Véase: http://collections.vam.ac.uk/item/O71781/one-flesh-collage-chadwickhelen/. Para un análisis de esta obra, véase McKellar, 2007: 202-212; Herles, 1997. 
cordón, y no la circuncisión, marca aquí el desdoblamiento de la vida neonatal: por un lado, la niña propiamente dicha (Cristo en el caso de la teología dogmática); por el otro, el gemelo o el alter ego representado por la placenta. Pero si bien la cristología dogmática se ha encargado de eliminar casi por completo la figura de la placenta (o al menos de reducirla a su dimensión humana, demasiado humana), la obra de Chadwick la restituye a su lugar esencial. Ahora, desde su altura soberana, la placenta nos dice que la niña no es una subjetividad autónoma y absolutamente hermética, sino "una subjetividad dividida o desdoblada" (McKellar, 2007: 207). La placenta instaura un espacio intermedio e irreductible entre las polaridades binarias de la metafísica (y en ese sentido se identifica con el dominio de las imágenes, más precisamente con los phantasmata) que es el locus específico del Anticristo, tal como nosotros lo entendemos: "Como el órgano que conduce nutrientes de la madre al niño, la placenta [es decir, el Anticristo] existe en el límite donde uno termina y el otro comienza" (2007: 205-206). Alienación originaria: Cristo, como imago Dei y a la vez como imago hominis, es decir como mediador y nexo conjuntivo, ha convivido desde el inicio con un otro irreductible, el Anticristo, phantasma Dei y a la vez phantasma hominis, un alius que sin duda es un alien, un Cristo-alien que los hombres, a partir de la Modernidad burguesa, parecen haber olvidado pero que vuelven a recordar, sin embargo, cada vez que se miran el ombligo. Esta expresión, "mirarse el ombligo", que en su uso coloquial significa la conciencia egoísta de pensar sólo en uno mismo, mienta, en su sentido teológico profundo, la extroversión del yo, la conciencia de que el yo está necesariamente fracturado, escindido y desdoblado en un otro fantasmático y espectral. En el caso de Cristo, este otro se llama Anticristo: el doble o gemelo placentario.

\section{REFERENCIAS}

Agamben, G. (2007). Ninfe. Torino: Bollati Boringhieri.

Alleau, R. (1958). De la Nature du Symbole. Paris: Flammarion.

Ambrosi, L. (1898). La psicologia della immaginazione nella storia della filosofía. Roma: Società Editrice Dante Alighieri.

Bargeman, L. A. (2005). The Egyptian Origin of Christianity. Nevada City: Blue Dolphin Publishing.

Belting, H. (2009). Imagen y culto. Una historia de la imagen anterior a la edad del arte. (C. D. Pampliega y J. E. Nuño, Trads.). Madrid: Akal.

Bollinger, L. (2007). Placental Economy: Octavia Butler, Luce Irigaray, and Speculative Subjectivity. Literature Interpretation Theory, 18(4), 325-352.

Bronfen, E. (1992). From omphalos to phallus: Cultural representations of femininity and death. Women: A Cultural Review, 3(2), 145-158. 
Brown, R. E. (1993). The Birth of the Messiah: A Commentary on the Infancy Narratives in Matthew and Luke. New York: Doubleday.

Cocking, J. (1991). Imagination: A Study in the History of Ideas. London: Routledge.

Crannell, P. W. (1932). The Supernatural Birth of (the) Christ. Review \& Expositor, $29(3), 347-362$.

Croft Long, E. (1963). The Placenta in Lore and Legend. Bulletin of the Medical Library Association, 51(2), 233-241.

Davidson, J. R. (1985). The Shadow of Life: Psychosocial Explanations for Placenta Rituals. Culture, Medicine and Psychiatry, 9(1), 75-92.

De Witt, F. (1959). An Historical Study on Theories of the Placenta to 1900. Journal of the History of Medicine and Allied Sciences, XIV(7), 360-374.

Deleuze, G. (1969). Logique du sens. Paris: Les Éditions de Minuit.

Emmerson, R. K. (1981). Antichrist in the Middle Ages A Study of Medieval Apocalypticism, Art, and Literature. Seattle: University of Washington Press.

Forsyth, N. (1987). The Old Enemy: Satan and the Combat Myth. Princeton: Princeton University Press.

Foucault, M. (2001). La prose d'Actéon. En Dits et écrits I (1954-1975). (pp. 326337). Paris: Gallimard.

Frazer, J. G. (1919). Folklore in the Old Testament. Studies in Comparative Religion Legends and Law. (vol. II). London: MacMillan and Co.

Gauchet, M. (1985). Le désenchantement du monde. Une bistoire politique de la religion. Paris: Gallimard.

Glick, L. B. (2005). Marked in your Flesh. Circumcision from Ancient Judea to Modern America. Oxford - New York: Oxford University Press.

Grillmeier, A. (1975). Christ in Christian Tradition. From the Apostolic Age to Chalcedon (451). (vol. I). Atlanta: John Knox Press.

Hegel, F. G. W. (1986). Enzylklopädie der philosophischen Wissenschaften im Grundrisse III, band 10. Frankfurt am Main: Suhrkamp.

Heidegger, M. (1961). Nietzsche, Band I. Deutschland: Neske.

Heidegger, M. (1997). Platons Lebre von der Wabrheit. Frankfurt am Main: Vittorio Klostermann.

Herles, E. (1997). Helen Chadwick: One Flesh, Christian Iconography and Motherhood. Exposure Magazine, 2nd Volume, 3rd Issue.

Hoben, A. (1908). Recent Discussions on the Virgin Birth of Christ. The American Journal of Theology, 12(2), 284-290.

Hughes, K. L. (2005). Constructing Antichrist. Paul, Biblical Commentary, and the Development of Doctrine in the Early Middle Ages. Washington D.C.: The Catholic University of America Press.

Irigaray, L. (1994). El cuerpo a cuerpo con la madre. Debate Feminista, 10, 32-44. Irigaray, L. (1993). Je, Tu, Nous. Toward a Culture of Difference. (A. Martin, Trad.). New York - London: Routledge.

Jacobs, A. S. (2012). Christ Circumcised: A Study in Early Christian History and Difference. Philadelphia: University of Pennsylvania Press.

Jenks, G. C. (1991). The Origins and Early Development of the Antichrist Myth. Berlin - New York: Walter de Gruyter. 
Juignet, P. (2003/2). Lacan, le symbolique et le signifiant. Cliniques méditerranéennes, (68), 131-144.

Kantorowicz, E. H. (1957). The King's Two Bodies. A Study in Mediaeval Political Theology. Princeton - New Jersey: Princeton University Press.

Lacan, J. (2006). El Seminario, Libro X, La angustia. Buenos Aires: Editorial Paidós. Lévy-Bruhl, L. (1931). Le surnaturel et la nature dans la mentalitéprimitive. Paris: Alcan. Loke, Y. W. (2013). Lifes Vital Link. The Astonishing Role of the Placenta. Oxford: Oxford University Press.

Lossky, V. (1967). À l'image et à la ressemblance de Dieu. Paris: Aubier - Montaigne. Lyons, J. (2005). Before Imagination: Embodied Thought from Montaigne to Rousseau. California: Stanford University Press.

Machen, J. G. (1958). The Virgin Birth of Christ. London: James Clarke \& Co. Ltd. McKellar, L. (2007). The Word Made Flesh: Re-embodying the Madonna and Child in Helen Chadwick's One Flesh. En G. Pollock y V. Turvey Sauron (Eds.). The Sacred and the Feminine. Imagination and Sexual Difference. (pp. 202212). London: I. B. Tauris \& Co. Ltd.

Merleau-Ponty, M. (1964). Le visible et l'invisible. Paris: Gallimard.

Miller, J. W. (2008). The Miracle of Christ's Birth. En J. H. Ellens (Ed.), Miracles. God, Science, and Psychology in the Paranormal. Volume 1. Religious and Spiritual Events. (pp. 117-134). Westport - Connecticut: Praeger.

Moody, D. (1953). On the Virgin Birth of Jesus Christ. Review \& Expositor, 50(4), 453-462.

Murray, M. A. (1930). The Bundle of Life. Ancient Egypt, 3, 65-73.

Nauta, L. \& Pätzold, D. (Eds). (2004). Imagination in The Later Middle Ages and Early Modern Times. Leuven - Paris - Dudley: Peeters.

Osman, A. (2005). Christianity: An Ancient Egyptian Religion. Vermont: Bear \& Co.

Parolini, O. (ed.). (2016). Placenta. The Tree of Life. London - New York: Taylor \& Francis Group.

Power, M. L. (2005). Birth, Distress and Disease. Placental-Brain Interactions. New York: Cambridge University Press.

Price, R. \& Gaddis, M. (Eds.). (2005). The Acts of the Council of Chalcedon. Liverpool: Liverpool University Press.

Prósperi, G. O. (2018). La respiración del Ser. Apnea y ensueño en la filosofía hegeliana. Buenos Aires: Miño y Dávila Editores.

Prósperi, G. O. (2015). Vientres que hablan: Ventriloquia y subjetividad en la historia occidental. La Plata: FaHCE-UNLP.

Rice, M. (2004). Egypt's Making. The origins of Ancient Egypt 5000-2000 BC. London - New York: Routledge.

Rohde, E. (1908). Psyche: Seelencult und Unsterblichkeitsglaube der Griechen. Tübingen - Leipzig: Verlag von J. C. B. Mohr.

Seligmann, C. G. y Murray, M. A. (1911). Note Upon an Early Egyptian Standard. Man, 11, 165-171.

Seth, C. (2013/1). À la recherche du Saint Prépuce. Littérature, (169), 5-18.

Sloterdjik, P. (1998). Sphären I. Blasen. Mikrosphärologie. Frankfurt am Main: Suhrkamp. 
Tertuliano. De carne Christi. J.-P. Mahé (Ed.), La chair du Christ. Tome I: Sources Chrétiennes. Paris: Cerf, 1975. D. E. Dekkers (Ed.), Corpus Christianorum. Turnhout: Brepols, 1954 (vol. II). E. Evans (Ed.), Tertullian's treatise on the Incarnation, latin and english, London: S.P.C.K., 1956.

Veenstra, J. R. (2004). The Subtle Knot. En L. Nauta y D. Pätzold (Eds), Imagination in The Later Middle Ages and Early Modern Times. (pp. 1-20). Leuven Paris - Dudley: Peeters.

Warner, M. (1976). Alone of All Her Sex. The Myth and Cult of the Virgin Mary. Oxford: Oxford University Press.

Wilkinson, J. (1964). Apologetic Aspects of the Virgin Birth of Jesus Christ. Scottish Journal of Theology, 17(02), 159-181.

Wray, T. J. y Mobley, G. (2005). The Birth of Satan: Tracing the Devil's Biblical Roots. New York: Palgrave MacMillan.

Sumario: Introducción; 1. El vientre y la placenta; 2. El gemelo fantasmático de

Cristo; 3. ¿Trasplante, cáncer o parásito?; 4. Plegaria para un órgano dormido; Conclusión; Referencias. 